\title{
Stewardship Accounting Practice by Government Ministries in Cameroon
}

\author{
Samuel Tanjeh Mukah ${ }^{1}$ \\ ${ }^{1}$ Department of Accounting and Finance, Higher Institute of Commerce and Management, University of Bamenda, \\ Cameroon \\ Correspondence: Samuel Tanjeh Mukah (Ph.D.), Department of Accounting and Finance, Higher Institute of \\ Commerce and Management, University of Bamenda, Cameroon.
}

Received: June 11, 2021

Accepted: July 14, 2021

Online Published: August 23, 2021

doi:10.5430/afr.v10n3p83

URL: https://doi.org/10.5430/afr.v10n3p83

\begin{abstract}
The study examined the practice of stewardship accounting by Government Ministries in Cameroon. It investigated how inclusive budget planning, timely budget execution, stringent budget control, and resolute scrutiny of government financial statements, affect the government stewardship accounting practice. To archive this, primary data collected from members of parliament were analysed, and regressed using the Ordinary Least Squares technique. The empirical results therefrom were of positive and statistical significance. They revealed that stringent budget control, and resolute scrutiny of government financial reports, significantly improve the practice of stewardship accounting in the Government Ministries. It was recommended that the government of Cameroon should frankly facilitate the participation of parliamentarians, civil society organisations, advocacy groups, and the citizens, in the budget preparation and execution processes. Such sincere participation invokes debates on problematic trade-offs and opportunity costs which are crucial in improving the wellbeing of Cameroonians. It was further recommended that parliamentarians should effectively play their role as representatives of the Cameroonian people, not withstanding their political inclinations. Consequently, they will not falter in their responsibility to resolutely scrutinise and authorise the budgets, and hold the Government and its Ministries fully accountable. The last recommendation was that Article 66 of the Cameroon Constitution (lying dormant since 2006) be put into practice. Article 66 provides for the declaration of assets by senior government officials, and others elected or appointed, at the beginning and at the end of their office tenures.
\end{abstract}

Keywords: stewardship accounting, accountability, budgets, parliament

\section{Introduction}

Stewardship accounting may be defined as an accounting practice where some people manage a variety of resources on behalf of the owners. Such managers are called stewards. Stewards have the obligation to provide relevant and reliable financial reports to the owners about the use or investment of such resources. The government of a nation governs on behalf of the citizens or stakeholders of that nation. It has the responsibility to plan, organise, direct, and control the use of the resources of the nation in a way that enables the citizens and the nation to experience growth and development in their wellbeing.

Consequently, the government be it at the national or local level has the obligation to render periodic accounts of its stewardship. The citizens through their representatives called members of parliament (MPs) or members of the house of assembly interrogate the government on the budget preparation, implementation, and control processes. In a democratic country, the citizens will retain or sanction the government based on the perception they have about the way their national resources are being managed.

There are some international instruments to which Cameroon is a signatory, and which lay down basic principles and concepts to ensure proper management of public affairs. The United Nations Convention against Corruption of 31 October 2003 supports actions aimed at efficiently and effectively detecting, preventing, fighting, and punishing acts of corruption; encouraging honesty in the management of public resources; giving of technical assistance to, and sharing information with member states in the fight against corruption (UN General Assembly, 2003).

In Cameroon, there are laws that ensure that the treasury properly safeguards public funds. For example Law No. $73 / 7$ of 7/12/1973) sanctions wrongdoings committed by persons handling the public funds and property; Law No. 
2003/005 of 21/04/2003 relating to the organisation and functioning of the Audit Bench of the Supreme Court whose main responsibility is to control and pass judgment on the accounts of public accountants in State institutions, public and semi-public establishments, regional and local authorities. The Cameroon Penal Code sanctions acts that violet public financial probity by public servants. Among the provisions in the Penal Code are Corruption (Article 134); Indulgence against the State (favoritism) (Article 137); and Article 184 on the misappropriation of public funds (Penal Code of Cameroon, 2016). There are decrees such as Decree No. 2004/275 of 24 March 2004 relating to the Public Contracts. It considers any violations of the provisions of the Public Contracts Code as misappropriation of public funds. Consequently, they should be sanctioned in accordance with the laws and regulations in force (Article $105(2))$.

Stewardship accounting should be applicable to both the public and private sectors of the economy. As concerns the public sector, public officers should be subjected to thorough examination by the parliament and/or senate over budget preparation and implementation. Cameroonian citizens expect the executive serving as stewards through its ministries to be accountable by being answerable for its actions. This expectation is in line with article 15 of the United Nations declaration of human and civic rights of 26 August 1789 which confers on the community the right to ask all public officials of funds and property (including those selected, elected, or appointed) to render account of their stewardship (UN Declaration, 1789). Rendering account suggests that a report, oral or written, be given to the citizens on whose behalf the resources are managed. In this respect, government ministers are obliged to assume responsibility for the results obtained following their actions or budget executions.

Furthermore, the UN convention against corruption has as one of the objectives to support the measures aimed at detecting, preventing, combating, and punishing acts of corruption in the management of public funds and property (UN Convention, 2004). By the same token, the African Union Convention on preventing and combating corruption of 11 July 2003 aims at encouraging member States to set up workable mechanisms to prevent, detect, punish and eradicate corruption and related offences in the management of public funds. Good public sector management therefore necessitates that vote holders be accountable. Logically, accountability of government ministers constitutes the foundation for the practical application of all other principles of good public sector management.

Article 66 of the Constitution of the Republic of Cameroon provides that senior officials of the State; holders of an elective office; General Managers of public and semi-public establishments; administrative personnel in charge of the tax base and the collection and handling of public funds; all budget authorising officers and vote-holders declare their assets and property at the beginning and at the end of their tenure of office (Constitution of Cameroon, 1996). Such declarations are expected to show the gap between what an official owned at the beginning and what he owns at the end of his tenure of office. Such a gap could indicate the occurrence or non-occurrence of misappropriation of public funds. Unfortunately, since the law was passed relating to the creation and organisation of the Commission in charge of the declaration of assets on the $16^{\text {th }}$ of April 2006, till date the members have not been appointed, thus making article 66 of the Cameroon constitution a farce.

Law No. 2007/006 of 26 December 2007 relating to the financial regime of the Cameroon State, reiterates that public projects or actions should be founded on general public interest. They should have clear indicators to measure their performances and the expected outcomes. Law No. 2007/006 also reiterates the reinforcement of parliamentary controls over government actions. Article 11 of the Cameroon constitution renders the government responsible to the National Assembly, thereby permitting the people to control government action through their representatives in parliament. Consequently, any act by public servants that violets financial probity and is considered injurious to public interest is qualified as an offence or crime. Examples are Corruption (Article 134); Interest in grants (Article 135); Interest in concern (Article 136); Indulgence against the State (Article 137); Misappropriation of public funds (article 184).

According to the World Bank Report (2018), the Cameroon government adopted a big programme in February 2009 for economic development and poverty reduction titled "Vision 2035." The main aim was to change Cameroon to become an industrialised, upper-middle-income country with low poverty rates, strong economic growth, and a functioning democracy. To realise this, the government adopted the Growth and Employment Strategy for 2010-2020, whose objectives, included: increasing the annual gross domestic product (GDP) growth rate to 5.5 percent; reducing the underemployment rate from 75.8 percent to less than 50 , and lowering the monetary poverty rate from 39.9 percent in 2007 to no more than 28.7 percent. Eleven years later, there is increasing fear of this vision being achieved given the discouraging level of accountability and transparency in government ministries, protracted domestic challenges such as violence in the North and Far North Regions, and the political crisis that germinated into war in the North West and South West Regions. 
Usually, public service entities are subject to a regular annual cycle of planning, performing, reporting, and scrutiny. In planning, activities to be carried out, priorities, and performance goals are clearly developed. Budget implementation or what may be called budget performing occurs when planned activities are carried out to agreed standards of quality, cost, and timeliness. In reporting, results of the work carried out are presented with proofs that there was cost-effectiveness during the process of execution or performance. The cycle ends up with scrutiny. In scrutiny, the reports are studied by the legislative body (representing the citizens of course) to confirm that public entities or ministries are properly accounting for their actions or performance.

The Cameroon government ministries have always been under heavy criticism for not carrying out their planned activities to agreed standards of quality, cost, and timeliness. Many projects started are soon abandoned, or poorly executed. The government financial reports do not go through meticulous scrutiny by the members of parliament whose fundamental role as people's representatives, is to authorise government budget decisions and hold government ministries accountable. The budgets and financial reports are deliberately given to MPs very late every year. This cause MPs to rush over them with little or no scrupulousness in assessing the practice of the government stewardship accounting.

With all this in mind, the broad objective of this paper was to assess the extent to which stewardship accounting is practiced by Government Ministries in Cameroon. Specifically the study assessed the extent to which inclusive budget planning, timely budget execution, budget control by members of parliament, and scrutiny of complete set of government financial statements by MPs, affect the practice of stewardship accounting by the Cameroon government ministries. The rest of the paper is organised in a way that section 2 carries a review of conceptual, theoretical, empirical literature, and the research gap. Section 3 designs the research methods that ensured the accuracy, quality and integrity of the empirical data collected. Presentation and discussion of the empirical data were discussed in section 4, while the findings, recommendations, and conclusion were given in section 5 .

\section{Related Literature Review}

The related literature reviewed is based on concepts, theories, and empiricism. Stewardship as a concept is defined by the World Health Organisation (2000) as "the careful and responsible management of the well-being of the population". It is described in general terms as "the very essence of good government". Stewardship according to this report is seen as the responsibility of the government managing the well-being of its population through the ministry of health. This should however, be extended to other government ministries. The government may not necessarily intervene and finance all operations that ensure the wellbeing of its citizens. Some of the stewardship responsibilities may be delegated to other actors depending on how the ministries are organised in a country (Saltman, and Ferroussier-Davis, 2000). The Archdiocese of Milwaukee (1993) described stewardship as a concept involving the grateful receipt of God's gifts, nurturing them responsibly, sharing them lovingly with others, and returning them with increase to God. All these views of stewardship stress the need to improve on the wellbeing of the people.

One of the functions of financial statements is to report on the discharge of stewardship responsibilities (Rosenfield, 1974). There are various views as to what stewardship responsibilities reported on in financial statements comprise. In general, they consist of safeguarding assets, and making progress towards the goals expected to be achieved by the stewards (Grady 1965, and May 1943). Making of progress is stated in terms of performance. That is, using assets gainfully, productively, and profitability. Wixon, Kell, and Bedford 1970 view Financial Reporting to be primarily concerned with reporting to outside parties. However, they maintain that its traditional premise is that of stewardship or accountability to those who supply the capital to the organisation and actors who contribute to the financial success or failure of the organisation. The American Accounting Association (1966) in a statement of basic accounting theory identified the objectives of accounting to include the provision of information for maintaining and reporting on the custodianship or stewardship of resources.

Stewardship accounting involves accountability. Accountability is a concept defined simply as having to be answerable to someone, for meeting defined objectives (Emanuel and Emanuel, 1996). Accountability takes financial, performance, and political/democratic dimensions (Brinkerhoff, 2004). The best ways to attain accountability still constitute a major priority of governments and private sectors. Deber (2014) asserts that a better understanding of accountability requires the specification of what is to be achieved, by whom, to whom, and how. It also includes rewards and punishments for archiving or not archiving defined objectives. In a nutshell, emphasis should be on using various methods that ensure that goals are met and performance improved upon.

Owojori, Akintoye, and Adidu (2009) cited Chartey (1987) as having defined accountability as those having custody of power being able to provide satisfactory, reliable, and accessible records and explanations on the use of public money and other resources. Accountability is described by Blagescu and de Las Casas (2005), O'Dwyer and 
Unerman (2007), as a relationship based commitment of some people to demonstrate, review, and take responsibility for their performance according to agreed expectations and resource use. Rutkowski and Steelman (2005) describe it as compliance and meeting of personal responsibilities, and an obligation to justify one's action to others.

These views of accountability resound the impression that when leaders are held accountable for their actions, they are obligated to use feedbacks to improve performance (Allen and Dennis, 2010; McCall, 2012). This could be very important in enhancing development and progress of a nation since the public feedback directs the debate and decision to elect people's representatives (Almquist et al., 2013). It can therefore be deduced that this process makes accountability a basis for democracy to thrive. In the public sector, governments are required to answer to the public by justifying the source and use of public resources (Almquist et al., 2013; Jorge de Jesus and Eirado, 2012). This is necessary because there are perceptions that the public sector is inefficient and poor in service delivery (Barton, 2006; Hui et al., 2011).

Accountability is therefore the rendering of returns by individuals or institutions on stewardship relating to the management of funds and other assets over which they had custody (Oke, 1988). Request for accountability should not be regarded in a negative light by those to account. Accountability should rather portray a potentially positive experience that allows agents (or stewards) to explain what they have been doing, thus enriching the roles they play (Keay, 2017). In this regard financial reporting has to be complete. A complete set of financial reporting or statements comprises according to the international public sector accounting standards (IPSAS) 1: Statements of financial position, financial performance, changes in net assets/equity, and Cash flow statement. In addition, the entity makes its approved budget publicly available, giving a comparison of budget and accrual amounts, notes, comprising a summary of significant accounting policies and other explanatory notes (Deloitte, 2021).

The Agency theory explains and conceptualises the role and behaviour of agents, including managers and directors of companies (Keay, 2017). According to the agency theory principals ensure that the agents act in the best interests of the principals instead of seeking to maximise their own personal interests (Pastoriza and Arinio 2008). Mukah (2016) posits that in the public sector, the citizenry and the tax payers constitute the principal or possessors of the public resources. On the other hand, the government ministers and directors who are users of the tax revenue constitute the agents who are supposed to work for the interest of the principal. Mukah (2016) further avows that sometimes the government seeks to maximise its personal interests instead of that of its citizenry or nationals. In this regard, tax payers and the public have the right to seek justice in accountability and transparency from the government executive and ministries by requesting for accurate, timely, reliable and complete financial reports.

Comparing the agency theory with the stewardship theory, the stewardship theory offers an alternative way of conceptualising the principal-agent relationship. It however, denies the existence of the problems portrayed by agency theory. Like agency theory, stewardship theory tries to explain the role and behaviour of directors (and in this case, ministers) in achieving organisational goals (Chrisman, et al. 2007). Like the agency theory, stewardship theory recognises that a form of agency exists in corporations. The stewardship theory fundamentally holds that agents (directors, managers, ministers) who act as stewards are not concerned about promoting their own economic interests. That is, they are not self-maximisers. Rather, they act in the best interests of their organisations/ministries so that collective and organisational interests instead of self-serving benefits are attained (Keay, 2017). The agency theory focuses on control and conflict while, the stewardship theory accentuates co-operation and collaboration (Sundaramuthy and Lewis, 2003).

The OECD principles of budgetary governance describes a budget as a contract between citizens and the state which shows how resources are raised and allocated for the delivery of public services. The process of building the budget should be inclusive. It should welcome contributions from many parties including parliamentarians, civil society organisations, advocacy groups, and even from citizens themselves. The principles recommend that discussions on budgetary choices should be inclusive, participative, and realistic. Governments are expected to facilitate the participation of all these actors to the budget process in truthful debates about problematic trade-offs, opportunity costs, and value for money (OECD, 2014). The national assembly is expected to play its fundamental role of legislating and controlling government actions. The control takes place when they authorise budget decisions and hold government ministers accountable by resolutely scrutinising government budgets and financial statements.

The main roles of the national assembly according to Lienert (2010) are to review and debate the government's draft ex-ante budget and to approve expenditure to execute the annual budget plan. The members of parliament also review the execution of the government budget. In some countries, MPs officially approve and discharge the government after annual budget execution. The parliament may also be involved in pre-budget debates, review of 
medium-term budget strategy by the government, approval of modifications on the initial budget adopted by the legislature, and examination of the external audit report.

Owojori, Akintoye, and Adidu (2009) carried out a study in Ekiti state in Nigeria to assess the political stewardship accounting for good governance. They posited that a political stewardship accounting system be put up and pursued in order to curb bad administration by public officials and politicians. They recommended financial accountability that ascertains the transparency of the government financial management of public funds.

In investigating the significance of accountability under the new approach to public governance, Hague (2000) postulated greater control and closer supervision over public and private financial and managerial matters. He recommended the introduction of stringent legislative mechanisms that ensure government budgetary scrutiny; laws that require ministries and agencies to ensure greater transparency, protection of press freedom to report official corruption and mismanagement. Furthermore, he commended an increase in the capacity and authority of all anti-corruption agencies, frequent use of opinion surveys to decrypt reactions of citizens whenever a public governance reform is introduced, and legislation requiring the written declaration of personal incomes and assets by all elected and appointed public officials before and after office. It is noteworthy that written declaration of property, shares, business relationships, and directorships in private corporations is required in countries such as Australia, Canada, Finland, Germany, Ireland, Mexico, Portugal, Sweden, the United Kingdom, and the United States of America (OECD, 1997). Unless this practice is emulated by other countries, and declaration made public like in the USA, there will still be growing number of public-private partnerships using autonomous public agencies for personal gains.

Safkaur et al. (2019) in a study on the effect of quality financial reporting on good governance asserted that the quality of financial statements has a significant effect on governance. This suggests that the more accounting information is free from bias making it accurate, reliable, complete, understandable, and timely, the better the quality of the financial statements and the governance system. Financial reporting is the main government tool of accountability to parliamentarians, other state institutions of interest, and the general public (Harun, 2009). Comprehensive Regional Government Financial Reports constitute one of the tools to facilitate the creation of public accountability (Mardiasmo, 2002). Public accountability is the obligation of the steward to provide accountability, present, report, and disclose all activities that are his responsibility to whoever has the right and authority to ask for that responsibility.

In accounting literature, stewardship is discussed extensively but not rigorously. Most of the time it is simply mentioned, or treated in a few words or statements. Hardly is any literature devoted exclusively to stewardship. It is in this regard that an attempt has been made in this study to examine stewardship accounting in the context of the Cameroon public sector.

\section{Methodology and Study Area}

This study took place in Cameroon, officially known as the Republic of Cameroon with a population estimate of $26,870,114$ as at January $1^{\text {st }} 2021$ (Cameroon population, 2021). It has some 240 native languages, and is a bilingual country speaking French and English (Presidency of the Republic, 2019). According to the presidential decree No. 2004/320 of $8^{\text {th }}$ December 2004 the Cameroon government comprises 32 ministries. These ministries normally should be the stewards or estate managers of the people of Cameroon.

A simple random sampling was effected to successfully obtain 21 out of 180 members of the lower house of the national assembly who participated in the study giving a percentage of $11.7 \%$. Twelve of them came from the ruling CPDM party (10 males and 2 females) while 9 males came from the opposition parties. All the members of parliament have had the experience of scrutinising the operations of government ministries in Cameroon for at least 5 years. In an online survey they freely, and confidentially responded to a questionnaire that sought to know the extent to which they play the role of people's representatives in the Cameroon parliament as it concerns scrutiny of government ministerial actions.

Using the Likert scale, an examination of the items was rated from 1 to 5, where: (5) = very strong, (4) = strong, (3) = fairly strong, $(2)=$ weak, and $(1)=$ very weak. The participants rated each parameter under examination according to their various degrees of perceptions. A regression analysis was later run to produce a regression output used in determining the effect of the independent variables on the dependent variable, stewardship accounting. Multiple regression models were employed. 
The indicators of stewardship accounting practice (SAP) were: inclusive budget planning (IBP), timely budget execution (TBE), budget control by MPs (BCMP), and resolute scrutiny of complete set of government financial statements (RSCSGFS) giving us the model:

$$
\mathrm{SAP}=\mathrm{f}(\mathrm{IBP}, \mathrm{TBE}, \mathrm{SBCMP} \text {, and RSCSGFS) }
$$

Given that the intersect coefficients, and the error term were to be estimated, the econometrics equation for the model was established as:

$$
\mathrm{SAP}=\beta_{0}+\beta_{1} \mathrm{IBP}+\beta_{2} \mathrm{TBE}+\beta_{3} \mathrm{BCMP}+\beta_{4} \mathrm{RSCSGFS}+\varepsilon \mathrm{i}
$$

Where:

$$
\begin{array}{ll}
\mathrm{SAP} & =\text { Stewardship application } \\
\mathrm{IBP} & =\text { Inclusive budget planning } \\
\mathrm{TBE} & =\text { Timely budget execution } \\
\mathrm{SBCMP} & =\text { Stringent budget control by members of parliament } \\
\mathrm{RSCSGFS} & =\text { Resolute scrutiny of complete set of government financial statements } \\
\beta 0 & =\text { Intersect } \\
\beta 1, \beta 2, \beta 3, \beta 4 & =\text { coefficients to be estimated } \\
\mathrm{Ei} & =\text { Error term }
\end{array}
$$

\section{Presentation and Discussion of Results}

Data gathered through the questionnaire was subjected to frequency counts. Personal information analysis was done on each respondent's political party, address, and longevity in parliament. To test for internal consistency, the study used the reliability instrument, Cronbach's Alpha. The results are presented on table 1.

Table 1. Cronbach's Alpha Values

\begin{tabular}{lccc}
\hline Variables & $\begin{array}{c}\text { Cronbach's } \\
\text { Alpha }\end{array}$ & $\begin{array}{c}\text { Cronbach's Alpha based } \\
\text { on standardised items }\end{array}$ & $\begin{array}{c}\text { Number of } \\
\text { Items }\end{array}$ \\
\hline Inclusive budget planning by government Ministries & 0.805 & 0.796 & 2 \\
Stringent budget control by MPs & 0.815 & 0.798 & 4 \\
Timely budget execution & 0.716 & 0.699 & 4 \\
$\begin{array}{l}\text { Resolute scrutiny of complete set of government } \\
\text { financial statements }\end{array}$ & 0.764 & 0.752 & 3 \\
Stewardship accounting practice & 0.811 & 0.789 & 3 \\
\hline
\end{tabular}

Source: Author's computation (2021)

One test of scale reliability involved examining whether items had an item loading of at least 0.70 , which demonstrates that the items shared more common variance with the construct than error variance (Carmines and Zeller, 1979). A second test was a measure of internal consistency developed by Fornell and Larcker (1981). The goal of this test was to achieve a score greater than 0.70 . The third and final common way to assess reliability was to examine Cronbach's coefficient alpha (Nunnally et al. 1994) where alpha scores that exceeded 0.70 are considered reliable. Table 1 shows that all the Cronbach's alpha values of the constructs have a value higher than 0.70 , indicating adequate internal consistency.

The Ordinary Least Squares technique was used to test the hypothesis of the study showing clearly the coefficients of the variables, t-statistics and their probability values. Their results are presented on table 2 . 
Table 2. Regression Results

\begin{tabular}{|c|c|c|c|c|c|c|}
\hline & \multirow[t]{2}{*}{ Model } & \multicolumn{2}{|c|}{ Unstandardised Coefficients } & \multirow{2}{*}{$\begin{array}{r}\text { Standardised } \\
\text { Coefficients } \\
\text { Beta }\end{array}$} & \multirow[t]{2}{*}{$\mathrm{T}$} & \multirow[t]{2}{*}{ Sig. } \\
\hline & & B & Std. Error & & & \\
\hline \multirow{5}{*}{1} & (Constant) & -1432.899 & 162.016 & & -8.844 & 0.000 \\
\hline & IBP & 0.040 & 0.037 & 0.077 & 1.065 & 0.297 \\
\hline & SBCMP & 0.444 & 0.042 & 0.051 & 10.600 & 0.000 \\
\hline & TBE & 0.007 & 0.010 & 0.014 & 0.731 & 0.471 \\
\hline & RSCSGFS & 940.542 & 93.440 & 0.232 & 10.066 & 0.000 \\
\hline
\end{tabular}

Dependent variable: Stewardship accounting practice

Source: Author's computation (2021)

The coefficient of inclusive budget planning by government ministries was positive (0.040), indicating a positive effect on stewardship accounting practice by government ministries. This implies that if the government ministries carry out inclusive budget planning it will influence the stewardship accounting practice by 0.040 unit. However, inclusive budget planning by government ministries is statistically insignificant in determining the level of stewardship accounting practice in the Cameroon government ministries.

The coefficient of stringent budget control by members of parliament (SBCMP) has a significant influence on stewardship accounting practice with a coefficient of 0.444. Hence, SBCMP has a positive significant effect on stewardship accounting practice at $5 \%$ level of significance. This is in line with the expectation of this study and in consonance with Hague (2000), OECD (1997), and Lienert (2010).

Timely budget execution (TBE) has a positive coefficient of 0.007 . This implies that the more regular the government ministries execute their budgets on time, the greater the practice of stewardship accounting becomes discernible in the government. This conforms to the a-priori expectation of the study even though the result turned out to be insignificant.

It is also noticed that resolute scrutiny of a complete set of government financial statements (RSCSGFS) has a positive coefficient of 940.542 . This is an indication that RSCSGFS significantly affects stewardship accounting practice by the government ministries. That is, the more regular the examination of complete set of government financial statements by members of parliament the higher the rate of stewardship accounting practice in the ministries. This is in line with a-priori expectations and matches with the findings of Owojori, Akintoye, and Adidu (2009), Safkaur (2019), Mardiasmo (2002), and Hague (2000).

To test for overall significance and the extent to which stewardship accounting is influenced by the combined change in all the independent variables, the f-statistics and the adjusted R-squared were used. Tables 3 and 4 illustrate the findings respectively.

Table 3. Test for overall Significance (F-statistics) ${ }^{\mathrm{a}}$

\begin{tabular}{lllllll}
\hline Model & & Sum of Squares & Df & Mean Square & F & Sig. \\
\hline 1 & Regression & 68425167.811 & 4 & 13685033.562 & 604.402 & $.000^{\mathrm{b}}$ \\
& Residual & 566056.899 & 96 & 22642.276 & & \\
& Total & 68991224.710 & 100 & & & \\
\hline
\end{tabular}

a. Dependent Variable: Stewardship accounting practice (SAP)

b. Predictors: (Constant), IBP, TBE, SBCMP, RSCSGFS

Source: Author's computation (2021)

The coefficient of the F-statistics is 604.402 with a probability value of 0.000 . This means that the overall model is very significant at 1 percent. That is, the model is more than 99 percent reliable in determining the level of stewardship accounting of government ministries in Cameroon. 
Table 4. Test for Multiple Determination (Adjusted R-squared)

\begin{tabular}{llllllllll}
\hline Model & $\mathrm{R}$ & R Square & $\begin{array}{l}\text { Adjusted R } \\
\text { Square }\end{array}$ & $\begin{array}{l}\text { Std. Error of } \\
\text { the Estimate }\end{array}$ & $\begin{array}{l}\text { R Square } \\
\text { Change }\end{array}$ & F Change df1 & df2 & Sig. F Change \\
1 & $.996^{\mathrm{a}}$ & .992 & .990 & 150.473506 & .992 & 604.402 & 4 & 96 & .000 \\
\hline
\end{tabular}

a. Predictors: (Constant), IBP, TBE, RSBCMP, SCSGFS

In addition to the overall test of significance, the R-squared is 0.990 . This shows that all the independent variables combined explain about $99 \%$ of the variations in the level of stewardship accounting practice. This in effect means a unit change in all of these variables will lead to a $99 \%$ change in the stewardship accounting. On the other hand, about $1 \%$ of the variations in the performance level are caused by changes in the other variables which were not included in the model of this study.

\section{Conclusion and Policy Implications}

This research empirically investigated how the practice of stewardship accounting by Government Ministries in Cameroon is affected by inclusive budget planning, timely budget execution, budget control by MPs, and resolute scrutiny of complete set of government financial statements by MPs. This was attained by collecting primary data from members of parliament (MPs), analysed and hypotheses regressed using the Ordinary Least Squares technique. The findings disclosed that stringent budget control by members of parliament, and resolute scrutiny of a complete set of government financial statements (Note 1) by the members of parliament significantly improve the practice of stewardship accounting by the government ministries in Cameroon.

The first recommendation is that the Cameroon government should facilitate the participation of all the stake holders especially the parliamentarians, civil society organisations, advocacy groups, and the citizens in the budget processes of preparation, implementation, and control. Such genuinely facilitated participation instigates debates on problematic trade-offs and opportunity costs. Such debates normally result in significant improvement in the wellbeing of the Cameroonian people, and also enable the Cameroon government to realise its economic development and poverty reduction programme called Vision 2035.

The second recommendation is that parliamentarians not withstanding their political inclinations (Note 2) should be deliberately conscious that they are the representatives of the people. In this respect, they have a central role to authorise budget decisions and hold the government (ministers) accountable when they resolutely scrutinise government budgets and financial statements. MPs should not be waylaid by the government by not giving them adequate time to do staid scrutiny of these reports. Rather, as law makers they must remind the government of the time limit allowed by the law to do so. In as much as the budget of the parliament is prepared independently from that of the government, the parliament itself should be subject to the same general procedures for stewardship accountability. They are not to abuse their powers by exaggerating their operating and investment expenses way out of tune compared to other national constitutional bodies like the judiciary.

The third recommendation is that Article 66 of the Cameroon 1972 Constitution as amended by Law No. 96-6 of $18^{\text {th }}$ January 1996 which provides that senior officials of the government, public and semi-public establishments (elected or appointed) declare their assets at the beginning and at the end of their tenure of office should be put into practice. A commission in charge of the declaration of assets whose law was created since the 16 April 2006, should be immediately appointed otherwise the article 66 of the Cameroon constitution remains a charade. An implementation of this article will curb illicit enrichment by many government ministers and directors, thus strengthening the practice of stewardship accounting in the Cameroon public sector.

\section{References}

American Accounting Association. (1966). A Statement of Basic Accounting Theory. Retrieved February 2021 from https://www.worldcat.org/title/statement-of-basic-accounting-theory/oclc/244212

Allen, J., \& Dennis, M. (2010). Leadership and accountability. Nursing Management. Harrow, London, England: 1994, 17(7), 28-29. https://doi.org/10.7748/nm2010.11.17.7.28.c8058

Almquist, R., Grossi, G., van Helden, G. J., \& Reichard, C. (2013). Public Sector Governance and Accountability. Critical Perspectives on Accounting, 24(7-8), 479-487. https://doi.org/10.1016/j.cpa.2012.11.005 
Archdiocese of Milwaukee. (1993). Stewardship: A Disciple's Response, Retrieved January 2021 from https://www.archmil.org/offices/development-stewardship/Concept-of-Stewardship.htm

Barton, A. D. (2006). Public sector accountability and commercial-in-confidence outsourcing contracts. Accounting, Auditing \& Accountability Journal, 19(2), 256-271. https://doi.org/10.1108/09513570610656114

Blagescu, M., \& de Las Casas, L. (2005). Pathways to Accountability. The GAP Framework. Retrieved from http://www.who.int/entity/management/partnerships/accountability/PathwaysAccountabilityGAPFramework.pd flnpapers2://publication/uuid/C35A1094-BC82-44A0-8C1C-77324A90CAC1

Brinkerhoff, D. W. (2004). "Accountability and Health Systems: Toward Conceptual Clarity and Policy Relevance." Health Policy and Planning, 19(6), 371-79. https://doi.org/10.1093/heapol/czh052

Deloitte. (2021). IPSAS in your pocket. Retrieved April 2021 from https://www.iasplus.com/en/publications/public-sector/ipsas-in-your-pocket-2021

Emanuel, E. J., \& Emanuel, L. L. (1996). “What Is Accountability in Health Care?” Annals of Internal Medicine, 124(2), 229-39. https://doi.org/10.7326/0003-4819-124-2-199601150-00007

Fornell, C., \& Larcker, D. F (1981). Evaluating Structural Equation Models with Unobservable variables and measurement error. Journal of marketing research. https://doi.org/10.1177/002224378101800104

Grady, P. (1965). Inventory of Generally Accepted Accounting Principles for Business Enterprises, Accounting Research Study, No. 7. https://core.ac.uk/download/pdf/288032915.pdf

Hague, M. S. (2000). Significance of Accountability under the New Approach to Public Governanc. International Review of Administrative Sciences, 66(4), 599-617. https://doi.org/10.1177/0020852300664004

Harun, H. (2009), Sector Accounting Reform and Public Sector Management in Indonesia. Jakarta: Jakarta Salemba Empat.

Hui, W. S., Othman, R., Omar, N. H., Rahman, R. A., \& Haron, N. H. (2011). Procurement issues in Malaysia. International Journal of Public Sector Management, 24(6), 567-593. https://doi.org/10.1108/09513551111163666

Jorge de Jesus, M., \& Eirado, J. S. B. (2012). Relevance of accounting information to public sector accountability: A study of Brazilian federal public universities. Tékhne, 10(2), 87-98. https://doi.org/10.1016/j.tekhne.2012.10.001

Keay, A. (2017) Stewardship Theory: Is Board Accountability Necessary? International Journal of Law and Management, 59(6), 1292-1314. https://doi.org/10.1108/IJLMA-11-2016-0118

Lienert, I. (2010). Role of the Legislature in Budget Processes. International Monetary Fund Fiscal Affairs Department. https://doi.org/10.5089/9781462398973.005

Mardiasmo. (2002). "Perpajakan". Edisi revisi; Yogyakarta. Penerbit Andi Offset. Retrieved March from http://eprints.ums.ac.id/30338/10/DAFTAR_PUSTAKA.pdf

May, G. O. (1943). Financial Accounting. New York: The Macmillan Company.

McCall, J. J. (2012). Leadership and ethics: Corporate accountability to whom, for what and by what means? Journal of Business Ethics, 38, 133-139.

Melog, A. (2013). Professional accounting standards and the public sector - a mismatch. Abacus, 41(2), 138-158. https://doi.org/10.1111/j.1467-6281.2005.00173.x

Mukah, S. T. (2016). Factors Influencing the Acceptance of International Public Sector Accounting Standards in Cameroon. Accounting and Finance Research, 5(2). https://doi.org/10.5430/afr.v5n2p71

Nunnally, J. C., Wiebe, S., Eliasziw, M., \& Matijevic, S. (1994). Journal of international League, 113 -118.

O'Dwyer, B., \& Unerman, J. (2007). From functional to social accountability: Transforming the accountability relationship between funders and nongovernmental development organisations. Accounting, Auditing \& Accountability Journal, 20, 446-471. https://doi.org/10.1108/09513570710748580

OECD. (2014). Principles of budgetary governance. Retrieved March 2021 from https://www.oecd.org/gov/budgeting/Draft-Principles-Budgetary-Governance.pdf

OECD. (1997). Managing the Senior Public Service: A Survey of OECD Countries. Paris: OECD. Retrieved March 2021 from https://www.oecd.org/gov/digital-government/1900113.pdf 
Oke, E. F. (1988). The concept of accountability. ICAN J. Vol. xxi (4).

Owojori, A. A., Akintoye, I. R., \& Adidu, F. (2009). Political stewardship accounting for good governance in Ekiti state, Nigeria. Journal of Accounting and Taxation, 1(3), 041-052. http://www.academicjournals.org/jat. DOI: $10.5897 / \mathrm{JAT} 09.019$

Pastoriza, D., \& Ariño, M. A. (2008). When Agents Become Stewards: Introducing Learning in the Stewardship Theory. https://doi.org/10.2139/ssrn.1295320

Penal Code of Cameroon. (2016). Retrieved January 2021 from https://www.wipo.int/edocs/lexdocs/laws/en/cm/cm014en.pdf

Presidency of the Republic of Cameroon. (2019). Cameroon. Retrieved March 2019 from https://www.prc.cm

Rosenfield, P. (1974). Objectives of financial statements: Selected papers American Institute of Certified Public Accountants, $\quad 2, \quad$ 123-140. $\quad$ Retrieved $\quad$ April 2021 from https://egrove.olemiss.edu/cgi/viewcontent.cgi?article=1702\&context=dl_tr

Rutkowski, K., \& Steelman, L. A. (2005). Testing a path model for antecedents of accountability. Journal of Management Development, 24(5), 473-486. https://doi.org/10.1016/S2212-5671(15)01096-5

Safkaur, O. et al. (2019). The Effect of Quality Financial Reporting on Good Governance. International Journal of Economics and Financial, Issues ISSN: 2146-4138. https://doi.org/10.32479/ijefi.8047

Saltman, R., \& Ferroussier-Davis, O. (2000). The concept of stewardship in health policy. Bulletin of the World Health Organization, 78(6), 733. Retrieved March 2021 from https://www.who.int/whr/2000/en/whr00_en.pdf

Sundaramuthy, C., \& Lewis, M. (2003). Control and Collaboration: Paradoxes of Governance. Academy of Management Review, 28, 397. https://doi.org/10.5465/amr.2003.10196737

UN Convention. (2004). United Nations Convention against Corruption. Retrieved March 2021 from https://www.unodc.org/documents/brussels/UN_Convention_Against_Corruption.pdf

UN Declaration. (1789). Declaration of human and civil rights of 26 august 1789. Retrieved March 2021 from https://www.conseil-constitutionnel.fr/sites/default/files/as/root/bank_mm/anglais/cst2.pdf

UN General Assembly. (2003). United Nations Convention against Corruption, A/58/422. Retrieved March 2021 from https://www.refworld.org/docid/4374b9524.html

Wixon, F., Kell, W. G., \& Bedford, N. M. (1970). Accountants' Handbook, Fifth Edition. New York: The Ronald Press Company. $\quad$ Retrieved $\quad$ Fenruary 2021 from https://www.amazon.com/Accountants-Handbook-Walter-Norton Bedford/dp/B0015NWPCC

World Bank Report. (2018). Cameroon public expenditure review. Aligning Public Expenditures with the Goals of Vision 2035. Retrieved in $\quad$ January 2021 from http://documents1.worldbank.org/curated/en/501141543353309471/pdf/124725-REVISED-Cameroon-public-e xpenditure-review-2018-FINAL.pdf

World Health Organization. (2000). The World health report: 2000: Health systems: improving performance. World Health Organization. https://apps.who.int/iris/handle/10665/42281

\section{Notes}

Note 1. Statements of financial position, statement of financial performance, statement of changes in net assets/equity, and a cash flow statement.

Note 2. The ruling party the Cameroon People's Democratic Movement (CPDM) parliamentarians who are in the majority tend to respect what they call 'Party discipline'. They tend not to act in the interest of their constituencies, but rather act in the interest of the ruling party. In this way, their decisions are significantly based on instructions from the party hierarchy whose chair person is the president of the country.

\section{Copyrights}

Copyright for this article is retained by the author(s), with first publication rights granted to the journal.

This is an open-access article distributed under the terms and conditions of the Creative Commons Attribution license (http://creativecommons.org/licenses/by/4.0/). 